\section{THE SIGNIFICANCE OF SALAHOEN AND KAIKAEO IN LILIT PHRA LO ${ }^{1}$}

\section{Cholada Ruengruglikit ${ }^{2}$}

\begin{abstract}
This paper examines the underlying meanings of salahoen, flying betel nut, and kaikaeo, the beautiful wild rooster, in "Lilit Phra Lo" or "The Tale of King Lo". "Salahoen" and "kaikaeo" are usually considered magical items sent by Pu Chao Saming Phrai, the Green Mountain Guardian, to aid Princess Phuean and Princess Phaeng in fulfilling their desire of acquiring King Lo's love. By using an anthropological approach, this study suggests that the "salahoen" might be an ordinary betel nut. It is a symbol of the princesses' love for King Lo, their invitation and gestures of warm welcome. As soon as King Lo receives these messages from the two princesses, whom he also desires romantically, he decides without any hesitation to leave his city to pursue his love. The custom of sending a betel nut as a symbol of love, invitation, and warm welcome as found in this tale is practiced among Tai people including Thais and various other peoples in Southeast Asian countries. In a similar vein, this study also claims that the "kaikaeo" may be interpreted as an
\end{abstract}

\footnotetext{
${ }^{1}$ Revised from a paper of the same title presented at the Sixth International Conference on Thai Studies held by Chiang Mai University, Chiang Mai Province, Thailand, October 14-17, 1996

${ }^{2}$ Associate Professor, Department of Thai, Faculty of Arts, Chulalongkorn University, Bangkok, Thailand
}

ordinary wild rooster whose significance lies in its roles in King Lo's life and destiny. As this paper reveals, King Lo wants to have the "kaikaeo" to relieve his anxiety and despair after receiving a bad prediction from the guardian of the Kalong River. The belief that a fowl may be used to take away one's misfortune and to foretell human fate exists in Thai and other Tai societies. Having unveiled the significance of the flying betel nut and the beautiful wild rooster in "the Tale of King Lo" from a cultural/anthropological perspective, this study then demonstrates that King Lo is fully aware of his actionsa factor that enables him to be a great tragic hero.

\section{Introduction}

Different interpretations lead to different understandings while studying the same object. This paper attempts to present a new and different interpretation of the salahoen, the flying betel nut, and of the kaikaeo, the surpassing wild rooster, in Lilit Phra Lo 'The Tale of King Lo' by employing a cultural/anthoropological perspective in order to bring readers to a better understanding of the hero's behavior.

\section{The background of Lilit Phra Lo}

Lilit Phra Lo was written in the early Ayutthaya period by an anonymous poet. ${ }^{3}$ Lilit Phra Lo is a tragic tale. This differentiates it from most Thai literary

\footnotetext{
${ }^{3}$ Although the word maharat 'great king' appears at the end of the tale in the last chapter of khlong si suphap meter, I believe this is not a reference to the poet. I suspect this word was added at a later date by court secretaries who copied this literary work and mistakenly assumed one of the Ayutthaya kings composed it.
} 
tales which usually have happy endings. Some Thai scholars, myself included, believe that Lilit Phra Lo was composed during the reign of King Ramathipbodi II (1491-1529) in the early Ayutthaya period. This dating is based on the literary conventions used, i.e., the versification and language, and on some archeological evidence mentioned in the story. (Sumonnachat 1994: 26-55; Cholada 1995: 26-55).

\section{A brief telling of Lilit Phra Lo}

Phra Lo was the king of Suang or Maen Suang City at the same time that Phra Phichaiphitsanukon was the king of Song City. These two cities were enemies because King Lo's father had led his army to invade Song City and killed Phra Phichaiphitsanukon's father, who ruled the city at that time. As a result, Phra Phichaiphitsanukon became king. Phra Phichaiphitsanukon's stepmother was determined to take revenge for her husband's death.

King Lo was very handsome. His exquisite good looks were acclaimed and widely praised until news of his beauty reached the ears of King Phichaiphitsanukon's two daughters, Princess Phuean and Princess Phaeng. They suddenly fell in love with him and desired him as their lover. They felt deep sadness because they could not find a way to fulfill their love. As soon as their two close attendants, Ruen and Roi, learned of the princesses' desire, they volunteered to help them. They played tricks by sending a singer to praise the beauty of their two princesses to King Lo. After listening to this song, King Lo made a puzzled gesture to the singer to indicate that he wanted the two princesses to be his loves. Having become aware of this message, Ruen and Roi asked several powerful magicians to lure King Lo to their princesses, but without success. At last, $\mathrm{Pu}$ Chao Saming Phrai, the Green Mountain Guardian, accepted this task. He tried several times to make King Lo come to meet the two princesses, but his attempts were in vain because the royal magician at King Lo's court dispelled the magic spells. Finally, $\mathrm{Pu}$ Chao Saming Phrai sent a spirit army to attack the spirit protectors of Song City. After Pu Chao Saming Phrai had learned that his spirit army had defeated that of Song City, he sent the salahoen, or flying betel nut, to King Lo. As soon as King Lo tasted it, he, together with his two close attendants, Kaeo and Khwan, and a group of soldiers, decided to leave his city for that of the princesses, despite his mother's protests. When he arrived at the Kalong River, which marked the boundary between the two kingdoms, he asked the river guardian to foretell his destiny and learned of his fatal misfortune. In spite of this foreknowledge, he continued on his journey and entered the frontier areas of Song City. Having waited for the arrival of King Lo for a long time, the two princesses sent their close attendants to Pu Chao Saming Phrai to ask him to speed King Lo's voyage. Thereupon, the powerful $\mathrm{Pu}$ Chao Saming Phrai sent a beautiful wild rooster, the kaikeao, to further attract King Lo. Seeing this rooster, King Lo immediately ran after it, pursuing it until he reached the garden of the princesses and waited for them there. Finally, the two princesses came to meet him and became his consorts. Afterwards, King Lo and his two close attendants, Kaeo and Khwan, secretly followed the two princesses back to their royal residence and lived there. After half a month, it began to be rumored that the princesses were hiding a man in theirquarters. When King Phichaiphitsanukon, the princesses' father, heard this rumor, he came to see for himself. Seeing King 
Lo's overwhelming beauty, King Phichaiphitsanukon acknowledged king Lo's merit and perseverance. Thus, he revealed himself and accepted King Lo as his son-in-law. However, King Phichaiphitsanukon's stepmother, the princesses' step-grandmother, held firm to her intention of taking revenge for her husband's death. She told the soldiers that King Phichaiphitsanukon's commanded them to kill King Lo, who was the enemy of Song City. The princesses' two close attendants, Ruen and Roi, and King Lo's two close attendants, Kaeo and Khwan, protected the princesses and King Lo until all four died. The princesses and King Lo continued fighting the soldiers until their royal bodies were pierced by numerous arrows. They died gracefully, leaning against one another. Remarkably enough, their deaths ended the enmity between their two cities.

\section{The significance of the Salahoen and the Kaikaeo in Lilit Phra Lo}

The salahoen, or flying betel nut, and the kaikaeo, the beautiful wild rooster, in Lilit Phra Lo play important roles in leading King Lo to the two princesses.

$\mathrm{Pu}$ Chao Saming Phrai sent the salahoen to King Lo after his ghost army had unsuccessfully attacked Suang City. After tasting the flying betel nut, King Lo immediately decided to leave his city and travel to see the two princesses. When he did not arrive as quickly as the princesses desired, Pu Chao Saming Phrai sent the beautiful rooster to provide additional enticement and lead him to the princesses' garden. There, King Lo and the two princesses met and fulfilled their love before they tragically met their deaths at the end of the tale. I would like to focus on the hidden cultural meanings of the salahoen and the kaikaeo as revealed through anthropological investigations.

\section{Salahoen as a symbol of love and a warm welcome presented to King Lo}

Considering the mountainous scenery and other details in the story, Thai readers tend to believe that this story took place in former times in the Kingdom of Lanna, or northern Thailand. It has been claimed that King Lo's city, Suang or Maen Suang City, is now Chaehom District in Lampang Province. It is also believed that the city of Princess Phuean and Princess Phaeng, Song City, is now the northern area of Rongkwang District in Phrae Province. This suggests that these two cities are, in fact, cities of Tai people.

In Tai society, as well as in certain other non-Tai Southeast Asian countries, a betel nut is used to express human relationships in the following ways.

\section{It is used to express the friendship of} the host. The host customarily brings a betel nut tray or betel nut box to greet his visitors. Failing to do so is a sign of the host's inhospitality (Sathirakoset 1958: 47). As for the guests, chewing the betel nut presented by the host signals an acceptance of the friendship offered.

This interpretation is supported by evidence from Thai history and literature. For example, after King Hongsawadi of Burma gained victory over Ayutthaya in the early Ayutthaya period in 1556, King Mahintharathirat, the reigning king of Ayutthaya at that time, was invited to meet King Hongsawadi at Wat Maheyong, a temple in Ayutthaya. King Hongsawadi handed King Mahintharathirat a betel nut and waited for him to chew it. After King Mahintharathirat had chewed the betel 
nut, King Hongsawadi tested King Mahintharathirat's sincerity by handing him a cuspidor so he could spit out his chewed betel nut, but King Mahintharathirat did not do so (Phra Ratchaphongsawadan 1954: 118-119). This showed that King Hongsawadi had offered King Mahintharathirat his friendship and King Mahintharathirat had not dared refuse.

In addition, if a host shows unwillingness while offering a betel nut tray or betel nut box to his guests, it could signify an unwilling welcome. This may also be seen in a Thai literary work of the early Rattanakosin, or Bangkok, period. At the end of Inao or the Thai Panji Story, when Chintara comes to Kalang City to be formally appointed as the hero's first queen. The heroine, Butsaba, welcomes Chintara by handing her a betel nut tray without paying a respectful greeting. Understanding Butsaba's feeling and message, Chintara receives the betel nut tray and then slams it down in front of Butsaba. This clearly reveals the unfriendly relationship between Butsaba, the hero's second queen, and Chintara, the hero's first queen.

Phraya Anumanratchathon has stated that the custom of welcoming guests by handing a betel nut or a betel tray was practiced among Tai people (including Thais). This custom came from southern India. In Indian tradition, the host welcomes his guests by handing them a betel nut. (Sathirakoset 1958: 47).

2. It is used to show the host's respect for his guests and vice versa. When a guest comes to the door, the host gives his guest a betel nut tray not only to invite him into his home but also to express his respect for that guest. This can be seen in the case of
Butsaba and Chintara, as has been mentioned before.

This usage can also be found in Thai wedding ceremonies. The bride customarily arranges for a girl to raise a betel nut tray to welcome the bridegroom and his attendants. The bridegroom is supposed to respond by presenting a well-prepared betel nut tray to the bride's parents to express his respect for them (Sathirakoset 1958: 86).

Additionally, in Lilit Phra Lo, at the beginning of the story, when $\mathrm{Pu}$ Chao Saming Phrai goes to visit the two princesses, Phuean and Phaeng, he receives a betel nut tray presented by the two princesses. His behavior brings happiness to the princesses (Literature 1986: 369). $\mathrm{Pu}$ Chao Saming Phrai's action indicates that he has accepted their respect and, at the same time, agreed to help lure King Lo to them.

3. It is used to express love for a man or for a woman. This use of the custom can be found in many Asian countries. Dr. Hong Lueang, a professor at the University of Hanoi, informs me that, among the Tai Terk in Vietnam, a girl or a woman who loves a man will give him a betel nut on which she has cast a spell in order to make him love and desire her (personal communication).

In Malaysian culture, on a couple's engagement day, a man customarily presents a betel nut tray to the parents of the woman to whom he is about to be engaged. This shows that he is asking for that woman's hand in marriage. If the woman's parents accept the betel nut tray, it means that they welcome him into their family (Sathirakoset 1958: 48). 
In Myanmar culture, a young woman also shows her preference for a particular young man by giving him a betel nut (Khin Myo Chit 1995: 80).

The Thai chronicle Phraratchaphongsawadan Krung Si Ayutthaya Chabap Phanchanthanumat (Choem) relates how Queen Sisudachan, wife of King Chairacha in the early Ayutthaya period, caught sight of a man called Phan Butsithep. She suddenly fell in love with him and ordered one of her maids to bring him a betel nut wrapped in a handkerchief as a gift from her. Upon receiving it, Phan Butsithep knew that the queen desired him. So he responded by sending an orange champaka, a kind of Thai flower, with the maid to bring to Queen Sisudachan (Phraratchaphongsawada 1954: 23).

In Lilit Phra Lo, Pu Chao Saming Phrai intentionally sends the salahoen, the flying betel nut, to King Lo. This betel nut might be interpreted as a symbol of the two princesses' love presented to King Lo. Moreover, the word flying in "the flying betel nut" possibly indicates that this symbol of the princesses' love is being sent to King Lo secretly. No one knows of this fact except him. Sending the salahoen to King Lo shows that the two princesses have selected King Lo to be their lover or shows their love for him and, at the same time, expresses a warm welcome towards him. In his work on Thai marriage customs, Prapheni Rueang Taeng Ngan Bao Sao Khong Thai, Phraya Anumanratchathon has stated that, in northern Thai culture, a girl or a young woman, not a man, selects her lover (Sathirakoset 1958: 7). So, we may assume that, King Lo receives and tastes the betel nut happily and thereupon decides to leave his city for that of the two princesses.
In the text, before $\mathrm{Pu}$ Chao Saming Phrai sends the salahoen to King Lo, he expresses the intention of his action clearly. He states that he is sending the salahoen to invite King Lo to come to the land of the two princesses (literature 1986: 376).

Some readers may argue that King Lo is under the spell of Pu Chao Saming Phrai at that time because the powerful $\mathrm{Pu}$ Chao Saming Phrai has cast an incantation on the flying betel nut before sending it to King Lo and this makes King Lo unable to resist the desire of the two princesses after he tastes it. While this interpretation is plausible on the surface, I believe that the interpretation presented here reveals a heretofore overlooked cultural aspect of the salahoen.

$\mathrm{Pu}$ Chao Saming Phrai's casting a spell on the flying betel nut does not have to be taken too seriously. It is not all that different from the Vietnamese girl casting a spell on a betel nut in her everyday life. Whenever she is pleased with a man and wants him to love her or to be her lover, she casts a spell by blowing on the betel nut and sending it to that man. She believes that this will make him return her love. This is a common belief in Tai society that is practiced in everyday life. Additionally, in Lilit Phra Lo, King Lo already wishes to meet the two princesses before tasting the flying betel nut but dares not go to meet them for certain serious but hidden reasons. At the beginning of the story, after listening to the song praising the surpassing beauty of the two princesses, King Lo expresses his desire for the two princesses to the singer. He also addresses a verse of khlong to the singer, expressing his desire for the two princesses to be his consorts. Briefly, he says that, after hearing the song praising the beauty of the two princesses, he feels as if both of them 
were at his side. In addition, King Lo shows his puzzled manner to the singer by raising one hand and placing it on his forehead. Then he raises his other hand, puts it on his chest, and gently fondles across it (Literature 1986: 361).

These events happen before $\mathrm{Pu}$ Chao Saming Phrai sends the flying betel nut to King Lo. This means that King Lo desires the two princesses as his consorts as soon as he hears the song. The puzzled expression of his desire for the princesses is sure to be reported to them and their two close attendants. So the princesses know as of that point that their desires are not different from King Lo's. This causes the princesses and their two close attendants to attempt to find additional means to fulfill their desires without any hesitation. However, at that time King Lo still does not know that the two princesses desire him. As a result, he dares not set foot in the land of the princesses, the land of his enemy. Until he receives the betel nut secretly sent to him by the two princesses, he does not realize that his wish could come true. Once he does, he decides to risk his life for his love.

\section{The Kaikaeo as an important creature for dispelling bad fortune or foretelling King Lo's destiny}

After King Lo passes the Kalong River, which marks the boundary between King Lo's and the princesses'domains, he takes his time getting to his final destination and does not arrive at the garden of the princesses quickly enough. $\mathrm{Pu}$ Chao Saming Phrai, whom the two princesses have again sent to speed King Lo's journey, decides to send the kaikaeo, the most beautiful of wild roosters, to guide him to his destination. Upon seeing this fowl, King Lo quickly chases after it until it vanishes in the air upon the successful completion of its task.

Most readers simply consider this rooster a beautiful magical creature. When King Lo sees it, he is attracted by its colorful feathers and graceful manner. As a result, he chases after it without any of his attendants. However, this interpretation presumes a certain level of ignorance and silliness on King Lo's part. If it were that easy for a beautiful rooster to misguide him while he was on his way to meet the princesses, then he would be a rather pitiful character.

The above interpretation is supported by the following factors:

1. The poet's description of this rooster's surpassing beauty. The text shows $\mathrm{Pu}$ Chao Saming Phrai calling all wild roosters from the forest to gather in front of him. He chooses the strongest and most beautiful one for this important task. This rooster has a long red line around its neck as if it were wearing a beautiful necklace. Additionally, its beauty, consisting of green feathers, five-colored wings, red edges along the eyelids, a red crest, golden-colored feet, and beautiful crowing sound, are elaborately described (Literature 1986: 401). I believe that this extensive description of the rooster's beauty has convinced most readers that it is precisely this beauty that attracts King Lo and lures him away from his destination.

The description of the rooster's beauty follows the tradition of describing the leading character's beauty or looks in descriptive scenes as practiced by ancient Thai poets. For example, the beauty of a disguised beautiful woman, the ghost of the dead Wanthong, is described when she appears to warn her son, Phra Wai, that he 
will be defeated in the war he is going to wage against his enemies (Sepha Rueang 2513: 1000). Phra Wai meets his dead mother, Wanthong, while he is marching to wage a war with a Mon army without knowing that it is, in fact, his father's army. Khun Phaen, his father, wants to take revenge on Phra Wai because Phra Wai hurt his own brother and khun Phaen's son, Plai Chumphon, when he was deeply in love with Soifa. As mentioned before, the poet's description of the important or leading character's beauty in each episode is often found in earlier Thai literature and does not necessarily mean that the leading character is actually extremely beautiful. It is a way of assigning importance or significance to a leading character who is about to perform an important task. Thus, the description of the kaikaeo's beauty could be considered part of the general or common style in conventional Thai writing.

\section{The popularity of classical Thai dance} performances of King Lo chasing after the beautiful fowl, an excerpt from Lilit Phra Lo. This might be another reason for many readers' ascription of significance to this rooster. In performances of the type called rabam, the rooster's beautiful and colorful feathers and its graceful manner are stressed and described. The more popular this dance is, the more convincing this interpretation becomes.

\section{The comparison of King Lo's chasing} after the beautiful rooster to other heroes' running after other beautiful creatures in other Thai literary works. Episodes of a beautiful animal luring the hero to a particular destination are not rare in Thai literature. These animals may take the form of golden deer, as seen in the Ramakian and Unnarut, or sometimes of a beautiful peacock, as can be found in Inao, and so on. All these creatures share a common characteristic: a beautiful appearance that effectively seduces the hero into chasing after it. In some instances, the creature's beauty attracts the hero's wife, and she asks the hero to catch it for her. The hero winds up meeting the heroine or sometimes being separated from his wife as a result.

The question of why a wild rooster was chosen to lure King Lo to the princesses deserves additional consideration.

Tai people mostly regard fowls, cocks, or roosters as beautiful creatures due to their beautifully colored feathers and wings, as evidenced by many Tai proverbs comparing the beautiful plumage of a fowl, a cock, or a rooster to a woman's beautiful clothing and adornments. Such proverbs are known among the central Thai, the northern Thai (also known as the Tai Lanna), the Tai Lue, the Tai Ahom, and others;

- A central Thai proverb states Kai ngam phro khon, khon ngam phro taeng. (ไก่งามเพราะขน คนงามเพราะแต่ง)

- A Tai Lanna proverb says kai ngam phuea khon, khon ngam phuea yong. (ไก่งามเพื่อขน คนงามเพื่อหย้อง)

- A Tai Lue proverb also says kai ngam phuea khon, khon ngam phuea khrueang. (ไก่งามเพื่อขน คนงามเพื่อเครื่อง)

- A Tai Ahom or Tai Yai proverb similarly states Kai rang di phuea khon, khon rang di phuea khrueang. (ไก่ร่างดีเพื่อ ขน คนร่างดีเพื่อเครื่อง $)^{4}$

\footnotetext{
${ }^{4}$ These proverbs have the same meaning that the beauty of chicken depends on their feather, the beauty of human depends on ornaments.
} 
Each of these proverbs equates approximately to the English: "a chicken is beautiful because of its plumage; a person is beautiful because of his/her clothes."

It is quite interesting that most Tai people share the idea that colored feathers bring beauty to a cock, a fowl, or a rooster. As a result, the rooster is a natural choice for the role of guiding King Lo to the two princesses. Its beauty is described to justify King Lo's attraction to it at first sight. However, I believe that the rooster's beauty is not the real reason why King Lo chases after it.

Though the wild rooster $\mathrm{Pu}$ Chao Saming Phrai sends to lure King Lo is often believed to be a magic creature, it could as easily be interpreted as an ordinary cock which is, nevertheless, very important to King Lo's life.

The two reasons I would adduce to explain King Lo's chasing after the rooster follow.

1. King Lo would like to use the rooster to dispel his bad fortune. The belief in using a cock to drive away bad fortune can be found in ancient Thai law, The Law of the Three Seals, in section 139. This law states that anyone fighting to the point of blood or delivering a child in the royal palace had to perform sacrificial worship. In this ritual, they had to sacrifice eight cocks to the guardian gods of the four entrances of the royal palace. At the end of the ritual, these cocks were cast outside the city in order to remove any bad omens or bad fortune (Kotmai 1994: 125-126).

As already mentioned, as soon as King Lo gets a negative prediction from the Kalong River guardian, he becomes sad and does not dare to share his grief with even his two closest attendants. During his journey, he is tortured by thoughts of this fatal destiny. Upon seeing the rooster, he may have had the idea of sacrificing the rooster to the god and letting this act drive the bad omen away.

2. King Lo would like to use the fowl to foretell his destiny once more. According to the belief of the Tai people, human destiny can be foretold by killing a cock or a fowl and studying the holes in its bones. This belief is discussed in Yiam Tai Ahom (Saranat 1954). When Lengdon, the King of Heaven, sends Thaen Kham's two sons-Khun Lung and Khun Lai-to rule the human world, he gives them a pair of cocks to foretell their destiny. When they arrive in the human world, they kill the two cocks. After studying the holes in their leg bones, they learn that both of them will become great kings (Saranat 1954: 109-120). The belief in the ability to foretell human fate by studying the holes in the bones of a cock still exists in many parts of Thailand, such as in Chiang Mai Province and Khorat Province. In northern Thailand, a cock's leg bones are usually used to perform this task, whereas, in the Northeast, a cock's chin bone is preferred. Given this belief, I am convinced that it is plausible to read King Lo as wanting to use the kaikaeo to foretell his destiny.

In the episode in which King Lo leaves his city for that of the princesses, he becomes very confused after arriving at the Kalong River and cannot decide whether he should continue his journey to meet the two princesses or whether he should return to his mother and his wife. He consults his two close attendants, Kaeo and Khwan. Though they advise him to go back, King Lo decides, nonetheless, to continue on his journey, because his desire to meet the princesses is stronger than his desire to 
return to his wife. In order to be sure that he has made the right decision, he asks the Kalong River guardian to foretell his destiny. He asks the river guardian to let the water flow down the river as usual if he will return to his city alive and to cause the water to flow upstream if he will not. Upon his uttering these words, the water not only begins flowing around in circles in front of his eyes but also becomes red as blood. Thus, he immediately knows his ultimate fate and, after that, his heart is filled with grief. He keeps the knowledge of his fatal destiny a secret, letting nobody, not even his two close attendants, know about it. In kingly pride, he goes on with his journey; however, he remains worried. So, when he catches sight of the beautiful rooster, he is extremely glad because it gives him a chance to dispel his bad fortune. He wants to kill the kaikaeo and to use its bones to predict his destiny and destroy the previous prediction he received from the Kalong River guardian.

However, King Lo's desire was not stated explicitly by the poet, and King Lo is, in the end, unable to catch the rooster; so, his real motive remains an enigma to most readers.

If one refuses this explanation of the function of the kaikaeo in the story, it raises the difficult question of whether it is reasonable for King Lo to change his mind so quickly after having undertaken such a long journey to meet the two princesses. Why does he waste his time running after a beautiful wild rooster which has just come to his sight? I am convinced that he would not do so if that rooster were not important to his life and fate.

\section{Conclusion}

This paper attempts to unveil the hidden meaning of the salahoen, or flying betel nut, and the kaikaeo, or beautiful wild rooster, in Lilit Phra Lo. Though the salahoen and the kaikaeo are usually considered magical items of $\mathrm{Pu}$ Chao Saming Phrai, they could as easily be interpreted as nonmagical items. This paper presents a new and different interpretation. This interpretation provides a logical explanation for King Lo's starting on a journey for love into the land of his enemy after having tasted the flying betel nut and for his running after the surpassing wild rooster upon seeing it. I believe that King Lo is perfectly conscious of what he is doing and bravely accepts his destiny even though he knows that he is in danger and that this danger might result in his death once he enters the hostile land. Thus, King Lo can also be considered a great tragic hero of classical Thai literature. His kingly pride, his bravery, his romantic love, and his remarkable death leaning against his two beloved princesses has captured readers' minds and made him a great and tragic hero never before encountered in Thai literature.

\section{References}

\section{Bot Lakhon Rueang Ramakian Phraratchaniphon Nai Phrabat Somdet Phra Phutthayotfachulalok (บทละครเรื่อง รามเกียรติ์ พระราชนิพนธ์ในพระบาทสมเด็จ พระพุทธยอดฟ้าจุพาโลก). $1967.4^{\text {th }}$ edition. Bangkok: Sinlapabannakhan. (In Thai)}

\author{
Bot Lakhon Rueang Unnarut \\ Phraratchaniphon Nai Phrabat \\ Somdet Phra Phutthayotfachulalok \\ (บทละครเรื่องอุณรุท พระราชนิพนธ์ใน
}


พระบาทสมเด็จพระพุทธยอดฟ้าจุพาโลก). 1972. $3^{\text {rd }}$ edition. Bangkok: Phrae Phitthaya. (In Thai)

Cholada Ruengruglikit. 1995. Lilit Phra Lo Taeng nai Samai Somdet Phra Ramathipbodi Thi Song: Sanapsanun Kho Sannitthan Khong M.R.W. Sumonnachat Sawatdikun (ลิลิตพระ ลอแต่งในสมัยสมเด็จพระรามาธิบดีที่ 2 : สนับสนุนข้อสันนิษฐานของ ม.ร.ว.สุมนชาติ สวัสดิกุล). In Phasa Lae Wannakhadi Thai 12: 26-55. (In Thai)

Cholada Ruengruglikit. 1996. The Significance of Salahoen and Kaikaeo in Lilit Phra Lo (ความสำคัญของสลาเหิน และไก่แก้วในเรื่องลิลิตพระลอ). In Proceedings of the Sixth International Conference on Thai Studies, Chiang Mai, Thailand 2, pp. 437-445. (In Thai)

Khin Myo Chit. 1995. Colorful Myanmar. $3^{\text {rd }}$ edition. Yangon, Myanmar: Parami Books.

The Law of the Three Seals (กฎหมายตราสาม ดวง). 1994. $3^{\text {rd }}$ edition. Vol. 1. Bangkok: Khurusapha. (In Thai)

Phraratchaphongsawadan Krung Si Ayutthaya Chabap Phanchanthanumat (Choem) kap Phra

Chakkraphatdiphong (Chat) (พระราช พงศาวดารกรุงศรีอยุธยา ฉบับพันจันทนุมาศ (เจิม) กับ พระจักรพรรดิพงศ์ (จาด)). 1954. Bangkok: Khlangwitthaya. (In Thai)
Rueang Inao Phraratchaniphon Nai Phrabat Somdet Phra

Phutthaloetlanaphalai (เรื่องอิเหนา พระ ราชนิพนธ์ในพระบาทสมเด็จพระพุทธเลิศหล้า นภาลัย). $1971.11^{\text {th }}$ edition. Thonburi, Thailand: Rungwatthana. (In Thai)

Saranat. 1954. Visting the Ahom Thai (เยี่ยม ไทยอาหม). Bangkok: Sathianraphap. (In Thai)

Sathirakoset [Phraya Anumanratchathon]. 1958. The tradition of Thai marriage (ประเพณีเรื่องแต่งงานบ่าวสาวของไทย). Bangkok: Rungrueang Tham. (In Thai)

Sepha Rueang Khun Chang-Khun Phaen (เสภาเรื่องขุนช้าง-ขุนแผน). 1970. $3^{\text {rd }}$ edition. Thonburi, Thailand: Bannakhan. (In Thai)

Sumonnachat Sawatdikun, 1994, June \& December. Sopsuan Rueang Kan Taeng Phra Lo (สอบสวนเรื่องการแต่ง พระลอ). In Phasa Lae Wannakhadi Thai 11: 26-55. (In Thai)

Literature in Ayutthaya period (วรรณกรรม สมัยอยุธยา). 1986. Vol.1. N.P.: Krom Sinlapakon. (In Thai) 